PENGARUH PENGGUNAAN DAUN SINGKONG SEBAGAI PAKAN SUPLEMEN TERHADAP PERFORMANS PRODUKSI DAN GEJALA REPRODUKSI TERNAK KERBAU YANG DIPERAH DIPELIHARA SECARA TRADISIONAL

ARTIKEL ILMIAH

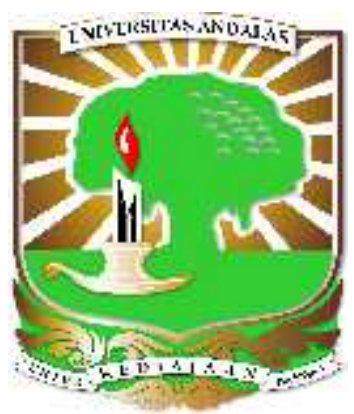

Oleh ELLY ROZA 0831201015

PROGRAM STUDI ILMU-ILMU PERTANIAN PROGRAM PASCASARJANA UNIVERSITAS ANDALAS PADANG 


\title{
PENGARUH PENGGUNAAN DAUN SINGKONG SEBAGAI PAKAN SUPLEMEN TERHADAP PERFORMANS PRODUKSI DAN GEJALA REPRODUKSI TERNAK KERBAU YANG DIPERAH DIPELIHARA SECARA TRADISIONAL
}

\author{
Oleh : Elly Roza, Suardi, Ellyza Nurdin dan Salam N Aritonang \\ Program Studi Ilmu Peternakan, Universitas Andalas \\ Kampus Unand Limau Manis Padang \\ Email : ell_roz@yahoo.com
}

\begin{abstract}
This study consisted of a series of in-vitro studies, surveys and in-vivo. The purpose of this study was to determine the use of cassava leaves as feed supplement on production performance and reproduction symptoms of milked buffaloes that reared traditionally. The material used in this study is the rumen fluid of buffaloes from Slaughterhouse Baleh Endah Bandung and feed supplements consisted of cassava leaves in pellet form. Variables measured were the characteristics of rumen fluid. The best results from this study are used for invivo studies in lactating buffalo producing of dadih with variables that, blood glucose and protein, milk production and quality, dadih production and quality and its organoleptic value, the health status of livestock by a decrease in faecal worm egg and reproduction symptoms of buffaloes. Results of in-vitro studies using $10 \%$ cassava leaf (Treatment B) as a feed supplement in pellets form on the characteristics of rumen fluid obtained normal rumen $\mathrm{pH}$ value is $\mathrm{pH} 6.0-7.0$ This condition can support the growth of rumen microbes work well in digesting the food fermentative and linked to the NH3, VFA, total bacteria, and KCBO $\mathrm{KCBK}$ that can support the fermentation process because the content is more complete nutrients. From in-vitro study was followed by the in-vivo studies. Results of in-vivo study showed that supplementation with feeding $1.5 \mathrm{~kg} /$ day can increase glucose and blood proteins buffaloes. The increasing of milk production is $0.96 \pm 0.04$ vs. $1.35 \pm 0.03 \mathrm{~kg}$ /days with milk composition: moisture $82.90 \% \pm 0.54$, protein $5.68 \pm 0.20 \%$, fat $8.10 \pm 0,20 \%$ and lactose $4.02 \pm 0.24 \%$ and increase blood glucose and protein. The use of cassava leaves as much as 1.5 $\mathrm{kg} /$ day producing good quality of dadih with composition: moisture content $80.93 \% \pm 0.38$, protein $7.95 \pm 0.68 \%$, fat $9.51 \pm 0.60 \%$, Lactic Acids Bacteri 2.22
\end{abstract}


$\pm 0.19\left(\times 10^{5}\right)$, acidity $1.22 \pm 0019$, viscosity of $2.68 \pm 0.11 \mathrm{Cpa}$. The use of cassava leaves on buffaloes can reduce worm eggs per gram of feces. While the use of $1.5 \mathrm{~kg}$ /days cassava leaves as feed supplement had no influence on the hormone prolactin, but influence the blood progesterone levels.

Key word: cassava leaves, milk production, quality of milk buffalo, dadih, reproduction

\section{PENDAHULUAN}

Upaya untuk memperbaiki produktivitas ternak kerbau yang dipelihara secara sederhana di lingkungan pedesaan dapat dilakukan melalui peningkatan kualitas bahan pakan. Cara yang sudah banyak dilakukan diantaranya melalui pemberian pakan suplemen berupa urea molasses multinutrient block (UMMB). Teknologi pakan suplemen ini diformulasikan dengan bahan-bahan seperti urea, molases, garam dan mineral serta bahan pakan lainnya yang tersedia di daerah setempat. Urea sebagai unsur non protein nitrogen dapat berperan meningkatkan status nutrisi dari pakan yang memiliki kualitas rendah.

Produksi susu kerbau lumpur di Sumatera Barat masih rendah, yaitu sekitar 1,50 \pm 0,53 liter/hari (Ibrahim, 2008) dengan lama laktasi 270-300 hari (Roza, 2009). Keterbatasan sumber hijauan/rumput lapangan yang berasal dari lingkungan sekitarnya dengan kualitas gizi yang rendah berdampak buruk terhadap produksi dan reproduksi ternak kerbau yang dipelihara peternak. Pemberian pakan suplemen pada sapi perah dapat meningkatkan pertumbuhan, produksi susu dan konsumsi pakan (Wanapat et al., 1999 dan Shamilima et al., 2000). Produksi susu pada sapi perah yang diberi jerami pada dengan tambahan pakan suplemen sebanyak 250 g/ekor/hari nyata meningkat dari 2,86 liter menjadi 4,43 liter/hari (Akter et al., 2004).

Kendala dalam penggunaan UMMB pada saat ini adalah terbatasnya ketersediaan urea yang umumnya digunakan sebagai pupuk pertanian di daerah pedesaan, selain juga harganya mahal. Alternatif untuk mengatasi masalah tersebut adalah dengan memanfaatkan bahan lain yang dapat digunakan sebagai sumber protein seperti daun singkong. Daun singkong atau ubi kayu (Manihot esculenta,Crantz) mempunyai potensi untuk dimanfaatkan sebagai komponen pengganti urea dalam pakan suplemen ini. Daun singkong yang telah dikeringkan 
(hay) merupakan sumber protein, dan dapat dimanfaatkan sebagai suplemen pada nutrisi ruminansia terutama pada sapi perah, sapi pedaging dan kerbau (Wanapat, 1993; Wanapat et al., 2000; Khang et al., 2005). Adapun pemberiannya dapat secara langsung sebagai suplemen pakan dan sebagai sumber protein dalam konsentrat (Wanapat et al., 2000; Hong et al., 2003) atau sebagai komponen bahan dalam pakan blok memiliki kualitas tinggi (Wanapat dan Khampa, 2006).

Tingginya protein by-pass dalam rumen yang dimiliki daun singkong merupakan faktor yang menyebabkan peningkatan kandungan lemak dan protein susu tersebut (Wanapat et al., 1997). Daun singkong kering mengandung protein 19,5\% bahan kering dan tanin terkondensasi 4,0\% bahan kering. Pemberian daun singkong kering pada kerbau lumpur sebanyak $1 \mathrm{~kg}$ bahan kering/ekor/hari nyata memperbaiki status nutrisi yang didasarkan pada kecernaan bahan kering, bahan organik, protein, konsumsi energi dan $\mathrm{NH}_{3}-\mathrm{N}$ rumen serta ekologi rumen. Selain itu, peranan tanin pada daun singkong dapat menurunkan jumlah telur cacing dalam feses sehingga status kesehatan ternak menjadi meningkat (Granum et al., 2007) Di samping itu, jumlah telur cacing dalam feses pada kerbau yang mendapat suplementasi daun singkong $1 \mathrm{~kg} /$ hari nyata lebih rendah (579 vs 1243 telur/gr BK feses), sedangkan pada sapi perah yang digembalakan dan diberi daun singkong dalam pakan blok menurut hasil penelitian Wanapat dan Kampa (2006), jumlah telur cacing dalam feses menurun 27,6\%. Mengacu pada kandungan protein yang cukup tinggi pada daun singkong dan ketersediaan tanaman tersebut cukup banyak serta mudah diperoleh di pedesaan, maka potensi penggunaannya dalam pakan suplemen untuk menggantikan keterbatasan penggunaan urea sebagai sumber nitrogen masih cukup tinggi.

Sehubungan uraian tersebut di atas, inovasi dan introduksi teknologi pakan suplemen dalam bentuk pellet diharapkan dapat meningkatkan status nutrisi, performans produksi dan reproduksi serta status kesehatan ternak kerbau. Tujuan penelitian ini adalah untuk mengetahui dosis daun singkong yang terbaik dalam pakan suplemen dapat meningkatkan karakteristik cairan rumen secara in-vitro, untuk mengetahui pengaruh penggunaan daun singkong sebagai pakan suplemen sebagai sumber protein terhadap performans produksi dan gejala reproduksi pada ternak kerbau. Hasil penelitian ini diharapkan dapat memberikan informasi teknis 
kepada peternak tentang pemanfaatan daun singkong sebagai pakan suplemen bentuk pellet dalam meningkatkan performans produksi dan gejala reprodukisi ternak kerbau dan dapat memberikan sumbangan untuk penggembangan ternak kerbau penghasil dadih di Sumatera Barat.

\section{MATERI DAN METODE PENELITIAN}

\subsection{Kondisi Padang Penggembalaan di Lokasi Penelitian}

Sebelum melakukan penelitian secara in-vitro dan in-vivo terlebih dahulu ditinjau kondisi padang penggembalaan ternak kerbau di Nagari Pematang Panjang, Kabupaten Sijunjung yang meliputi: komposisi botanis, produksi hijauan, kapasitas tampung, potensi maksimum lahan dan nilai gizi hijauan ternak.

\section{Penelitian Tahap I - Penelitian In vitro}

Tujuan penelitian ini untuk mengetahui pengaruh penggunaan daun singkong sebagai pakan suplemen terhadap karakteristik cairan rumen dan melihat level yang terbaik dari perlakuan tersebut. Bahan utama yang digunakan dalam penelitian ini adalah pellet yang berasal dari Daun Singkong dan bahan-bahan lain penyusun pellet (Tabel 1). Cairan rumen sebagai donor mikroba diambil dari rumah potong hewan (RPH) Bale Endah-Bandung (Jabar) dengan tambahan larutan Mc Dougall's sebagai buffer.

Tabel 1.Komposisi Bahan dalam Pakan Suplemen Bentuk Pellet Menurut Komposisi Tepung Daun Singkong (\%)

\begin{tabular}{lcccc}
\hline \multicolumn{1}{c}{ Bahan } & $\begin{array}{c}\text { Pakan A } \\
(\%)\end{array}$ & $\begin{array}{c}\text { Pakan B } \\
(\%)\end{array}$ & $\begin{array}{c}\text { Pakan C } \\
(\%)\end{array}$ & $\begin{array}{c}\text { Pakan D } \\
(\%)\end{array}$ \\
\hline Urea & 10,0 & 7,5 & 5,0 & 2,5 \\
Saka & 20,0 & 20,0 & 20,0 & 20,0 \\
Dedak padi & 45,0 & 37,5 & 30,0 & 22,5 \\
TDS* & 0,0 & 10,0 & 20,0 & 30,0 \\
Semen & 10,0 & 10,0 & 10,0 & 10,0 \\
Garam & 8,0 & 8,0 & 8,0 & 8,0 \\
Mineral mix & 2,0 & 2,0 & 2,0 & 2,0 \\
Air & 5,0 & 5,0 & 5,0 & 5,0 \\
\hline Jumlah & 100 & 100 & 100 & 100 \\
\hline
\end{tabular}

Keterangan : *) tepung daun Singkong

Perlakuan yang diberikan adalah level Daun Singkong sebagai Pakan

Suplemen dalam konsentrat, sebagai berikut: A. Pakan A + $0 \%$ Pakan Suplemen Daun Singkong. B. Pakan B $+10 \%$ Pakan Suplemen Daun Singkong C. Pakan 
C $+20 \%$ Pakan Suplemen Daun Singkong D. Pakan D + 30\% Pakan Suplemen Daun Singkong. Penelitian ini menggunakan Rancangan Acak Lengkap (RAL) dengan 4 Perlakuan dan 4 Ulangan Peubah yang di amati adalah Karakteristik cairan rumen yaitu Kadar $\mathrm{pH}$, Konsentrasi $\mathrm{NH}_{3}$, VFA total, Total Bakteri, Kadar KCBK dan KCBO cairan rumen

\section{Penelitian Tahap Kedua / Penelitian Lapangan/In-vivo}

Tujuan penelitian ini untuk mengetahui pengaruh penggunaan pakan suplemen daun singkong terhadap performans produksi dan gejala reproduksi ternak kerbau. Bahan utama yang digunakan dalam penelitian ini adalah pakan suplemen yang dibuat dalam bentuk pellet dengan campuran bahan konsentra lainnya (Tabel 1) hasil yang terbaik (perlakuan B) dari penelitian sebelumnya (invitro). Penelitian ini menggunakan 20 ekor kerbau betina laktasi 2 dan 3 dengan kisaran umur 4-5 tahun di peternakan kerbau Kanagarian Pamatang Panjang, Kecamatan Sijunjung, Kabupaten Sijunjung.

Rancangan yang digunakan dalam penelitian ini adalah Rancangan Acak Lengkap (RAL) dengan 4 perlakuan dan 5 ulangan. Perlakuan yang diberikan adalah: A.Pemberian Pakan Suplemen Daun Singkong 0 kg/ekor/hari. B.Pemberian Pakan Suplemen Daun Singkong 0,5 kg/ekor/hari. C.Pemberian Pakan Suplemen Daun Singkong 1,0 kg/ekor/hari D. Pemberian Pakan Suplemen Daun Singkong $1,5 \mathrm{~kg} / \mathrm{ekor} / \mathrm{hari}$

\section{Peubah yang diamati}

Glukosa dan protein Darah, produksi susu dan komposisi susu, produksi susu di standarkan dengan 7\% FCM Menurut Hayashi et al.,(2007). kualitas dadih, penghitungan jumlah telur cacing serta pengaruh pakan suplemen terhadap estrus pertama pospartum, hormon progesteron dan prolaktin.

\section{HASIL DAN PEMBAHASAN}

Komposisi Botani. Komposisi Botani padang pengembalaan alam di lokasi penelitian lebih tinggi golongan Gramineae $(62,06 \%)$ dibandingkan dengan leguminoseae $(23,80 \%)$ dan Browse $(14,14 \%)$.

Produksi Hijauan. Produksi padang pengembalaan alam di lokasi penelitian masih tergolong rendah yaitu 3,123 ton/ha/th. Hal ini disebabkan oleh jenis tanaman (komposisi botanis) yang kurang baik karena lebih didominasi oleh 
rumput pahit dan alang-alang yang mempunyai produktivitas rendah, serta banyaknya browse (gulma) yang tumbuh di padang pengembalaan alam. Produksi hijauan di kebun karet cukup tinggi yaitu 5,75 ton/ha/th sedangkan produksi jerami padi juga cukup tinggi yaitu 32,66 ton/ha/th, namun pemanfaatannya dalam pakan ternak kerbau belum digunakan. Sedangkan produksi jerami jagung yaitu 5,75 ton/ha/th merupakan hal yang sangat potensial untuk dimanfaatkan sebagai pakan ternak.

Kapasitas Tampung. Hasil kapasitas tampung hijauan di padang pengembalaan alam yaitu 0,59 ST/ha/th. Menurut Reksohadiprodjo (1981) kapasitas tampung beberapa pasture yang baik adalah 2,50 ST/ha/th. Kapasitas tampung hijauan di kebun karet yaitu 1,08 ST/ha/th, hasil ini cukup tinggi dibandingkan hijauan di padang pengembalaan alam, karena kondisi tanah yang lebih subur dan telah mengalami perlakuan seperti pemupukan.Kapasitas tampung jerami padi dan jerami jagung sudah cukup baik. Kapasitas jerami padi 11,18 $\mathrm{ST} / \mathrm{ha} /$ tahun dan jerami jagung 5,11 ST/ha/th, dibandingkan penelitian Ilyas (1995), menyatakan bahwa kapasitas tampung jerami padi berkisar antara 2,003,00 ST/ha/th dan jerami jagung 5,00-6,00 ST/ha/th.

Potensi Maksimum Lahan. Jumlah PMSL (Potensi Maksimum Sumberdaya Lahan) di lokasi peneitian yaitu 5.947,93 ST dengan populasi riil (jumlah ternak ruminansia) 891,09 ST dan KPPTR (kapasitas peningkatan populasi ternak ruminanisa) 5.056,88 ST yang didapat dari selisih Jumlah PMSL dan Populasi Riil. Jika peternak hanya mengandalkan padang pengembalaan alam sebagai sumber pakan maka kebutuhan ternak akan hijauan tidak akan terpenuhi secara optimal. Untuk padang pengembalaan alam 30,68 ST dengan jumlah ternak yang cukup banyak yaitu 891,09 ST tidak akan memenuhi kebutuhan ternak. Hal ini disebabkan produktivitas padang pengembalaan alam daerah ini masih rendah disamping luas padang pengembalaan alam yang tersedia hanya 52,00 ha.

Hasil limbah pertanian seperti jerami padi dan jerami jagung di lokasi penelitian cukup melimpah. Jerami padi dapat dijadikan sebagai pakan ternak sebanyak 3.454,62 ST, jerami jagung 413,91 ST dan hijauan di kebun karet 2.048,76 ST. Keadaan ini dapat meningkatkan daya tampung ternak, sehingga bisa meningkatkan populasi ternak ruminansia sebanyak 5.056,88 ST. 


\section{Penelitian In-Vitro}

\section{Pengaruh Pakan Suplemen Daun Singkong terhadap Karakteristik Cairan Rumen}

Hasil penelitian pengaruh pemberian pakan suplemen daun singkong terhadap karakteristik cairan rumen dapat dilihat pada Tabel 2.

Tabel 2. Rataan $\mathrm{pH}$, Konsentrasi $\mathrm{NH}_{3}$, Total Bakteri, Produksi VFA, KCBK dan KCBO, Hasil Penelitian

\begin{tabular}{lcccc}
\hline \multirow{2}{*}{ Peubah } & \multicolumn{4}{c}{ Perlakuan } \\
\cline { 2 - 5 } & $\mathrm{A}$ & $\mathrm{B}$ & $\mathrm{C}$ & $\mathrm{D}$ \\
\hline $\mathrm{pH}$ & $6,94^{\mathrm{Aa}}$ & $6,94^{\mathrm{a}}$ & $6,84^{\mathrm{ab}}$ & $6,76^{\mathrm{Bb}}$ \\
$\mathrm{NH} 3(\mathrm{mg} / 100 \mathrm{ml})$ & $14,32^{\mathrm{Aa}}$ & $13,37^{\mathrm{ABb}}$ & $11,97^{\mathrm{BCc}}$ & $11,24^{\mathrm{Cc}}$ \\
VFA (mM) & $90,00^{\mathrm{Dd}}$ & $114,75^{\mathrm{Aa}}$ & $106,75^{\mathrm{Bb}}$ & $99,25^{\mathrm{Cc}}$ \\
BAKTERI(10 $\left.{ }^{9} \mathrm{CFU} / \mathrm{ml}\right)$ & $44,42^{\mathrm{Aa}}$ & $60,95^{\mathrm{a}}$ & $50,95^{\mathrm{ab}}$ & $34,45^{\mathrm{Bb}}$ \\
KCBK$(\%)$ & $53,84^{\mathrm{Bb}}$ & $62,19^{\mathrm{Aa}}$ & $63,73^{\mathrm{a}}$ & $46,64^{\mathrm{Cc}}$ \\
KCBO$(\%)$ & $64,36^{\mathrm{Bb}}$ & $67,52^{\mathrm{Aa}}$ & $66,73^{\mathrm{a}}$ & $62,90^{\mathrm{Bc}}$ \\
\hline
\end{tabular}

Keterangan : Superskrip yang diikuti huruf kecil yang berbeda pada baris yang sama berbeda nyata $(\mathrm{P}<0,05)$ dan dengan huruf besar berbeda sangat nyata $(\mathrm{P}<0,01)$.

pH cairan rumen. Hasil Uji DMRT menunjukkan bahwa $\mathrm{pH}$ pada perlakuan D sangat nyata paling rendah dibanding perlakuan lainnya namun berbeda tidak nyata dengan perlakuan $\mathrm{C}$ sedangkan perlakuan $\mathrm{A}$ dengan $\mathrm{B}$ berbeda tidak nyata. Tidak berbedanya perlakuan A dan B karena dengan pemberian pakan suplemen daun singkong sebanyak $10 \%$ belum mempengaruhi $\mathrm{pH}$ cairan rumen. Nilai $\mathrm{pH}$ yang diperoleh dalam penelitian ini berada pada kondisi optimal untuk menjamin pertumbuhan dan aktifitas mikroba rumen $(\mathrm{pH}$ 6,30 - 7,00) (Orskov, 1982). Hasil penelitian ini tidak jauh berbeda dengan hasil penelitian Foiklang et al. (2011) yaitu pemberian daun singkong kering yang diberikan pada kerbau lumpur menghasilkan $\mathrm{pH}$ rumen 6,60. Ini menunjukkan bahwa keadaan rumen masih normal dan bakteri masih dapat berkembang.

Konsentrasi NH3. Hasil Uji DMRT menunjukkan bahwa konsentrasi $\mathrm{NH}_{3}$ pada perlakuan D sangat nyata paling rendah dibanding perlakuan A dan B namun tidak berbeda nyata $(\mathrm{P}>0,05)$ dengan perlakuan $\mathrm{C}$. Hal ini disebabkan penggunaan daun singkong merupakan bahan sumber protein by pass yang mengandung tanin yang bersifat memproteksi protein dari proses fermentasi oleh mikroba rumen sehingga protein yang terdegradasi lebih rendah dari perlakuan A (kontrol) akibatnya NH3 yang merupakan hasil penguraian protein pun lebih rendah pula. 
Produksi VFA total (Volatile Fatty Acid). Hasil uji lanjut DMRT menunjukkan bahwa VFA total pada perlakuan B sangat nyata paling tinggi yaitu $114.75 \mathrm{mM}$ dibanding perlakuan $\mathrm{C}, \mathrm{D}$ dan yang paling rendah pada perlakuan A. Paling tingginya total VFA pada perlakuan B sejalan dengan peningkatan kecernaan zat makanan, namun semakin tinggi level pakan suplemen yang diberikan pada perlakuan C dan D semakin rendah total VFA yang dihasilkan, hal ini sejalan dengan kecernaan yang semakin rendah, karena VFA merupakan hasil akhir fermentasi karbohidrat oleh mikroba rumen. Peningkatan kadar VFA menunjukkan peningkatan kandungan protein dan karbohidrat pakan yang mudah larut. Pada ruminansia VFA berperan sebagai sumber energi bagi ternak dan sumber kerangka karbon untuk pertumbuhan protein mikroba (Sutardi, 1980).

Total Bakteri Rumen. Hasil uji lanjut DMRT menunjukkan bahwa total bakteri rumen pada perlakuan B (pemberian 10\%) sangat nyata paling tinggi namun tidak berbeda nyata dengan perlakuan $\mathrm{A}$ dan $\mathrm{C}$ dan berbeda nyata dengan perlakuan D. Total mikroba rumen menunjukkan tingkat fermentasi dalam rumen, semakin tinggi aktifitas fermentasi semakin bertambah total mikroba rumen (Czerkawski,1986). Total bakteri rumen hasil penelitian ini masih dalam batas kisaran normal yaitu berkisar antara $10^{9} \mathrm{CFU} / \mathrm{ml}$ sampai $10^{12} \mathrm{CFU} / \mathrm{ml}$ sesuai dengan yang dikemukakan oleh Ogimoto dan Imai (1981) dan Fuller (1992)

Kecernaan Bahan Kering. Hasil uji lanjut DMRT menunjukkan bahwa kecernaan bahan kering perlakuan $\mathrm{C}$ sangat nyata $(\mathrm{P}<0,01)$ paling tinggi dibanding dengan perlakuan $\mathrm{A}$ dan $\mathrm{D}$, namun berbeda tidak nyata $(\mathrm{P}<0,05)$ dengan perlakuan B. Kecernaan bahan kering pada perlakuan B dan C nyata paling tinggi disebabkan karena pemberian pakan suplemen sampai $20 \%$ dapat meningkatkan aktifitas bakteri rumen dalam pembentukan bakteri sellulotik untuk degradasi karbohidrat menjadi monosakarida atau glukosa. Namun pemberian pakan suplemen yang lebih tinggi sampai $30 \%$ pada perlakuan D dapat menurunkan kecernaan bahan kering.

Kecernaan Bahan Organik. Hasil uji DMRT menunjukkan bahwa kecernaan bahan organik pada perlakuan B sangat nyata paling tinggi namun berbeda tidak nyata dengan perlakuan $\mathrm{C}$, sama halnya dengan kecernaan bahan kering. Hal ini disebabkan bahwa peningkatan kecernaan bahan kering diikuti 
dengan kecernaan bahan organik karena kecernaan bahan kering berbanding lurus dengan kecernaan bahan organik. Peningkatan kecernaan bahan organik dan bahan kering disebabkan meningkatnya populasi dan aktifitas mikroba dalam rumen karena tersedianya nutrien secara cukup dan seimbang. Hal ini sesuai dengan pendapat Preston dan Leng (1987) bahwa pertumbuhan mikroba dalam rumen memerlukan amonia sebagai sumber pembentuk protein mikroba yang harus tersedia dalam karbohidrat dan energi yang dihasilkan.

\section{Penelitian Lapangan/In-vivo}

\section{Pengaruh Penggunaan Daun Singkong dalam Pakan Suplemen terhadap Glukosa dan Total Protein Darah}

Rataan pengaruh penggunaan daun singkong sebagai pakan suplemen terhadap glukosa dan protein darah pada ternak kerbau dapat dilihat pada Tabel 3 Tabel 3. Rataan Glukosa dan Total protein darah Ternak kerbau Hasil Penelitian

\begin{tabular}{ccccc}
\hline \multirow{2}{*}{ Peubah } & \multicolumn{4}{c}{ Perlakuan } \\
\cline { 2 - 5 } & $\mathrm{A}$ & $\mathrm{B}$ & $\mathrm{C}$ & $\mathrm{D}$ \\
\hline Glukosa $(\mathrm{mg} / \mathrm{dl})$ & $80,29 \pm 4,04^{\mathrm{c}}$ & $85,43 \pm 3,82^{\mathrm{b}}$ & $86,82 \pm 1,18^{\mathrm{b}}$ & $91,83 \pm 4,41^{\mathrm{a}}$ \\
Total Protein $(\mathrm{g} / \mathrm{dl})$ & $6,25 \pm 0,26^{\mathrm{b}}$ & $6,81 \pm 0,36^{\mathrm{a}}$ & $7,20 \pm 0,32^{\mathrm{a}}$ & $7,11 \pm 0,41^{\mathrm{a}}$ \\
\hline Ketrangan $:$ Superkip
\end{tabular}

Keterangan : Superskrip yang diikuti huruf kecil yang berbeda pada baris yang sama berbeda nyata $(\mathrm{P}<0,05)$ dan dengan huruf besar berbeda sangat nyata $(\mathrm{P}<0,01)$.

Glukosa Darah. Hasil uji lanjut DMRT menunjukkan bahwa kadar glukosa darah pada perlakuan D sangat nyata paling tinggi dibandingkan perlakuan lainnya, sedangkan kadar glukosa darah pada pelakuan $\mathrm{C}$ berbeda tidak nyata dengan perlakuan B dan yang paling rendah adalah kadar gula darah pada perlakuan A. Hal ini menunjukkan bahwa pemberian pakan suplemen daun singkong sangat nyata meningkatkan kadar glukosa darah.

Tingkat glukosa darah dianggap sebagai salah satu indikator status energi bagi ruminansia. Tingginya glukosa darah seiring dengan meningkatnya pemberian pakan suplemen daun singkong karena di dalam pakan suplemen daun singkong selain mengandung protein juga merupakan sumber karbohidrat, yang akan dirombak oleh mikroorganisme menjadi asam lemak terbang diantaranya asam propionat yang merupakan prekursor dalam pembentukan gula darah. Seperti yang dikemukakan oleh Bergma et al. (1966), bahwa glukosa darah dapat 
berasal dari berbagai sumber diantaranya adalah asam propionat. 50\% dari asam propionat yang diabsorbsi dirombak menjadi glukosa dan $40 \%$ disintesis menjadi senyawa-senyawa lain. Demikian juga pendapat Leng et al. (1967) menyatakan, bahwa 54\% glukosa tubuh berasal dari asam propionat. Asam propionat diabsorbsi dari rumen akan dirombak menjadi glukosa dalam hati.

Protein Darah. Hasil uji DMRT menunjukkan bahwa total protein darah pada perlakuan $\mathrm{C}$ sangat nyata paling tinggi dengan perlakuan A tetapi berbeda tidak nyata dengan perlakuan B dan D. Keadaan ini menunjukkan bahwa peningkatan pakan suplemen daun singkong meningkatkan total protein darah.

Mikroba rumen menghasilkan enzim - enzim protease yang memecah protein pakan menjadi oligopeptida. Oligopeptida yang terbentuk digunakan untuk menyusun protein mikroba dan sisanya akan melalui proses selanjutnya menjadi asam amino dan akan mengalami deaminasi menjadi asam keto alfa dan ammonia. Proses ini terjadi terus - menerus, tanpa menghiraukan adanya akumulasi amonia dalam rumen (Sutardi, 1977). Menurut Wanapat et al. (2006), amonia tersebut digunakan oleh mikroba sebagai sumber nitrogen utama untuk sintesis protein mikroba, karena prekursor pembentukan protein mikroba yang selanjutnya dibentuk menjadi protein tubuh adalah $\mathrm{NH}_{3}$

\section{Pengaruh Pakan Suplemen Terhadap Produksi dan Komposisi Susu Kerbau}

Hasil penelitian tentang produksi dan komposisi susu kerbau yang diberi pakan suplemen dapat dilihat pada Tabel 4.

Tabel 4. Rataan Produksi Dan Komposisi Susu Kerbau (Kadar Protein, Lemak, Air dan Laktosa ) Hasil Penelitian

\begin{tabular}{|c|c|c|c|c|}
\hline \multirow{2}{*}{ Peubah } & \multicolumn{4}{|c|}{ Perlakuan } \\
\hline & A & B & $\mathrm{C}$ & D \\
\hline Produksi Susu(kg) & $0,96 \pm 0,04^{\mathrm{d}}$ & $1,10 \pm 0,06^{\mathrm{c}}$ & $1,20 \pm 0,02^{\mathrm{b}}$ & $1,35 \pm 0,03^{\mathrm{a}}$ \\
\hline Air $(\%)$ & $85,36 \pm 0,79^{a}$ & $83,92 \pm 0,51^{\mathbf{b}}$ & $83,92 \pm 0,48^{\mathbf{b}}$ & $82,90 \pm 0,54^{\mathrm{c}}$ \\
\hline Protein $(\%)$ & $4,69 \pm 0,15^{\mathrm{c}}$ & $4,98 \pm 0,52^{\mathbf{b c}}$ & $5,20 \pm 0,21^{\mathbf{b}}$ & $5,68 \pm 0,20^{\mathrm{a}}$ \\
\hline Lemak (\%) & $6,28 \pm 0,43^{c}$ & $6,86 \pm 0,60^{\mathbf{b}}$ & $7,13 \pm 0,25^{\mathbf{b}}$ & $8,10 \pm 0,32^{\mathbf{a}}$ \\
\hline Laktosa (\%) & $3,17 \pm 0,29^{\mathbf{b}}$ & $3,17 \pm 0,18^{\mathbf{b}}$ & $3,41 \pm 0,33^{\mathbf{b}}$ & $4,02 \pm 0,24^{\mathrm{a}}$ \\
\hline
\end{tabular}

Keterangan : Superskrip yang diikuti huruf kecil yang berbeda pada baris yang sama berbeda nyata $(\mathrm{P}<0,05)$ dan dengan huruf besar berbeda sangat nyata $(\mathrm{P}<0,01)$.

Produksi Susu.. Hasil uji lanjut DMRT menunjukkan bahwa produksi susu pada perlakuan $\mathrm{D}$ nyata paling tinggi $(\mathrm{P}<0,05)$ dibandingkan perlakuan 
lainnya. Persentase peningkatan produksi susu dengan pemberian pakan suplemaen daun singkong dibanding tanpa pemberian pakan suplemen berturutturut $14,40 \%, 25 \%$ dan $40 \%$ atau rata-rata 1,67 lt/ekor/hari. Hal ini menunjukkan bahwa peningkatan pemberian pakan suplemen daun singkong menghasilkan produksi susu yang semakin tinggi, hasil penelitian ini lebih tinggi dari yang dilaporkan Wirdahayati dan Bamualim (2007) produksi susu kerbau sebesar 1,1 lt/ekor/hari.

Meningkatnya produksi susu kerbau seiring dengan peningkatan penggunaan daun singkong dalam pemberian pakan supplemen disebabkan, daun singkong mengandung nitrogen yang merupakan precursor dalam pembentukan $\mathrm{NH}_{3}$ di dalam rumen. Adapun $\mathrm{NH}_{3}$ dimanfaatkan sebagai sumber nitrogen bagi pertumbuhan mikroorganisme, sehingga aktivitas mikroorganisme di dalam rumen dalam memfermentasi polisakarida menjadi asam lemak terbang (VFA) meningkat pula. VFA digunakan sebagai sumber energi oleh ternak untuk berproduksi. Lebih tingginya produksi VFA, maka ternak kerbau mendapatkan sumber energi yang lebih besar sehingga produktivitasnya menjadi lebih baik, ditandai dengan lebih tingginya produksi susu. Hal ini sesuai dengan pernyataan Suryahadi et al. (2003) bahwa peran suplementasi pakan nyata dalam memperbaiki metabolisme dan dapat meningkatkan kemampuan mikroba dalam mendegradasi pakan dalam rumen.

Kadar Air. Hasil uji DMRT menunjukkan bahwa kadar air dalam susu pada perlakuan D nyata paling rendah dibandingkan perlakuan lainnya. Kadar air susu pada perlakuan $\mathrm{C}$ berbeda tidak nyata dengan perlakuan B. Ini berarti bahwa pemberian pakan suplemen daun singkong sangat nyata menurunkan kadar air dari susu. Menurunnya kadar air susu kerbau seiring dengan meningkatnya pemberian pakan suplemen daun singkong, karena kandungan laktosa yang berbeda. Sekresi air dalam susu sangat dipengaruhi oleh laktosa yang bersifat isotonis. Untuk mempertahankan osmosanya supaya isotonis dengan darah dibutuhkan produksi laktosa. Jika kekurangan laktosa dapat mengurangi sekresi air ke dalam susu sehingga produksi susu berkurang karena kandungan air dalam susu melalui sel-sel epitel dan masuk kedalam susu secara filtrasi. Sekresi air mempunyai hubungan erat dengan tekanan osmosa dari susu (Wikantadi, 1978). 
Protein Susu. Hasil uji DMRT menunjukkan bahwa kadar protein susu kerbau pada perlakuan D sangat nyata paling tinggi dibandingkan perlakuan lainnya. Kadar protein susu pada perlakuan $\mathrm{C}$ berbeda tidak nyata dengan perlakuan B. Hal ini menunjukkan bahwa kadar protein susu kerbau meningkat seiring dengan meningkatnya pemberian pakan suplemen daun singkong.

Peningkatan kadar protein susu seiring dengan meningkatnya pemberian suplemen daun singkong, karena di dalam daun singkong mengandung protein $(33,3 \%)$ dan asam amino yang mudah didegradasi oleh mikroba rumen yaitu 5,6\% valin, 8,3\% leusin dan 4,2 isoleusin (Phuc et al., 2008) dan juga daun singkong kaya akan protein mudah larut (Jalaludin, 1994). Daun singkong juga sebagai sumber asam amino rantai bercabang, yang merupakan sumber kerangka karbon yang dibutuhkan untuk menstimulir pertumbuhan bakteri selulolitik. Tanpa kerangka karbon, amonia tidak bisa digunakan untuk sintesis protein mikroba rumen. Peningkatan kadar protein susu juga disebabkan oleh kandungan tanin terkondensasi dalam singkong yang berperan dalam membentuk tanin-protein kompleks dan meningkatkan protein by pass di dalam rumen, sehingga daun singkong sebagai sumber protein tambahan dapat meningkatkan produksi dan komposisi susu.

Lemak Susu. Hasil uji DMRT menunjukkan bahwa kadar lemak susu pada perlakuan D sangat nyata paling tinggi dibandingkan perlakuan lainnya, sedangkan kadar lemak susu perlakuan $\mathrm{C}$ dan perlakuan $\mathrm{B}$ berbeda tidak nyata dan perlakuan A paling rendah.

Paling tingginya kadar lemak susu kerbau yang diberi pakan suplemen daun singkong $1,5 \mathrm{~kg}$ pada perlakuan D disebabkan karena pakan suplemen berfungsi sebagai sumber karbohidrat mudah terlarut dan protein lolos degradasi. Adapun karbohidrat merupakan precursor glukosa yang dalam proses fermentasi oleh mikroorganisme rumen akan menghasilkan VFA diantaranya asam asetat sebagai pembentukan lemak susu dengan demikian pemberian pakan suplemen yang semakin tinggi maka akan meningkatkan jumlah karbohidrat yang terlarut dan protein yang lolos degranasi sehingga juga akan meningkatkan glukosa yang telah difermentasi oleh mikroba menjadi VFA. VFA total pakan suplemen daun singkong adalah 114.75mM sedangkan VFA partial (asetat 73,80 (\%molar); 
propionat 22,40(\% molar) dan butirat 15,21 (\%molar). Disini terlihat bahwa tingginya asam asetat yang tersedia untuk pembentukan produksi susu terutama kadar lemak yang tinggi. Asam asetat sangat diperlukan untuk pembentukan lemak susu dan mempunyai hubungan positif dengan lemak susu yang dihasilkan (Siregar, 1999).

Laktosa. Hasil DMRT menunjukkan bahwa kadar laktosa susu pada perlakuan D sangat nyata paling tinggi dibandingkan perlakuan lainnya, namun di antara perlakuan A, B dan C satu sama lain berbeda tidak nyata.

Tingginya kadar laktosa susu kerbau seiring dengan meningkatnya pemberian pakan suplemen daun singkong, dalam pakan suplemen daun singkong selain mengandung protein juga merupakan sumber karbohidrat, yang akan dirombak oleh mikroorganisme menjadi asam lemak terbang diantaranya asam propionate yang merupakan prekursor dalam pembentukan gula darah sebagai bahan baku pembentuk laktosa susu. Glukosa dapat berasal dari berbagai sumber diantaranya adalah asam propionat. Hasil penelitian Bergman et al. (1966) menemukan bahwa $50 \%$ dari asam propionat yang diabsorbsi diubah menjadi glukosa dan $40 \%$ disintesis menjadi senyawa-senyawa lain. Sementara leng et al . (1967) menemukan bahwa 54\% glukosa tubuh berasal dari asam propionate yang dihasilkan asam lemak terbang.

Asam propionat setelah diabsorbsi dari rumen dan akan dirubah menjadi glukosa dalam hati. Glukosa ini sebagian dirobah menjadi glikogen dan disimpan dalam hati atau dirubah mejadi $\alpha$-gliserol fosfat dan digunakan untuk mensintesa trigliserida. Sisa glukosa akan dibawa rnelalui peredaran darah ke berbagai jaringan tubuh yang akan digunakan sebagai sumber energi, sumber ko-enzim, pereduksi dalam sintesis asam lemak dan glikogen otot (Riis, 1983; Benerjee, 1980). Kecukupan protein dan energi ransurn akan meransang aktivitas mikroba rumen sehingga menghasilkan asam propionat yang lebih banyak (Banerjee', 1980)

\section{Pengaruh Pemberian Pakan Suplemen Terhadap Kualitas Dadih}

Rataan kualitas dadih pada ternak kerbau laktasi yang diberi pakan suplemen Daun Singkong dapat dilihat pada Tabel 5. 
Tabel 5. Rataan Kadar Lemak, Protein, Air, Viskositas, BAL dan Keasaman Dadih Pada Ternak Kerbau Laktasi Yang Diberi Pakan Suplemen

\begin{tabular}{lcccc}
\hline \multirow{2}{*}{ Peubah } & \multicolumn{4}{c}{ Perlakuan } \\
\cline { 2 - 5 } & $\mathrm{A}$ & $\mathrm{B}$ & $\mathrm{C}$ & $\mathrm{D}$ \\
\hline Kadar Air (\%) & $82,00 \pm 0,55^{\mathrm{a}}$ & $81,86 \pm 0,59^{\mathrm{a}}$ & $81,67 \pm 0,18^{\mathrm{a}}$ & $80,93 \pm 0,38^{\mathrm{b}}$ \\
\hline Kadar Protein (\%) & $6,59 \pm 0,28^{\mathrm{b}}$ & $7,30 \pm 0,38^{\mathrm{a}}$ & $7,70 \pm 0,47^{\mathrm{a}}$ & $7,95 \pm 0,68^{\mathrm{a}}$ \\
Kadar Lemak (\%) & $7,80 \pm 0,43^{\mathrm{b}}$ & $8,28 \pm 0,28^{\mathrm{b}}$ & $8,93 \pm 0,42^{\mathrm{a}}$ & $9,51 \pm 0,60^{\mathrm{a}}$ \\
BAL (x 10 & $1,41 \pm 013^{\mathrm{c}}$ & $1,71 \pm 012^{\mathrm{b}}$ & $2,03 \pm 017^{\mathrm{a}}$ & $2,19 \pm 019^{\mathrm{a}}$ \\
CFU/ml) & & & \\
Keasaman (\%) & $1,07 \pm 0,49^{\mathrm{c}}$ & $1,16 \pm 0,03^{\mathrm{b}}$ & $1,20 \pm 0,02^{\mathrm{a}}$ & $1,22 \pm 0,11^{\mathrm{a}}$ \\
Viskositas (Cpa) & $1,85 \pm 0,12^{\mathrm{c}}$ & $2,04 \pm 0,17^{\mathrm{b}}$ & $2,55 \pm 0,15^{\mathrm{a}}$ & $2,68 \pm 0,11^{\mathrm{a}}$ \\
\hline Keterangan : Superskrip yang diikuti huruf kecil yang berbeda pada baris yang \\
\multicolumn{4}{c}{ sama berbeda nyata (P<0,05) dan dengan huruf besar berbeda } \\
sangat nyata (P<0,01).
\end{tabular}

Kadar Air Dadih. Hasil uji DMRT menunjukkan bahwa kadar air dadih pada perlakuan D sangat nyata paling rendah dibandingkan perlakuan lainnya, sedangkan perlakuan A, B dan C tidak berbeda nyata. Ini berarti bahwa pemberian pakan suplemen daun singkong sangat nyata menurunkan kadar air dadih.

Menurunnya kadar air dadih akibat pemberian pakan suplemen daun singkong disebabkan pakan suplemen tersebut mengandung protein dan karbohidrat yang dapat meningkatkan kualitas susu terutama protein susu. Dalam proses pembuatan dadih Bakteri Asam Laktat (BAL) akan merombak laktosa menjadi asam laktat sehingga asam laktat yang dihasilkan meningkat. Meningkatnya asam laktat dalam dadih akan meningkatkan total padatan, yang diikuti oleh penurunan kandungan air dadih sehingga penggumpalan protein susu menjadi curd juga meningkat.

Protein Dadih. Hasil uji DMRT menunjukkan bahwa kadar protein dadih pada perlakuan D nyata paling tinggi dibandingkan perlakuan lainnya, tetapi berbeda tidak nyata dengan kadar protein dadih pada perlakuan B dan C. Ini berarti bahwa pemberian pakan suplemen nyata meningkatkan kadar protein dadih.

Meningkatnya kadar protein dadih seiring dengan meningkatnya pemberian pakan suplemen daun singkong disebabkan pakan suplemen mengandung protein mudah larut (Jalaludin, 1994) dan sumber asam amino rantai bercabang, yang merupakan sumber kerangka karbon yang dibutuhkan untuk 
menstimulir pertumbuhan bakteri selulolitik. Bakteri selulolitik sangat responsif terhadap penambahan kerangka karbon bercabang (Nurhaita et al., 2010) sehingga penambahan konsentrat pakan suplemen yang semakin meningkat (perlakuan D), kadar protein dalam susu juga semakin meningkat.

Lemak Dadih. Hasil uji DMRT menunjukkan bahwa kadar lemak dadih pada perlakuan D sangat nyata paling tinggi $(9,51 \%)$ dibandingkan perlakuan lainnya, tetapi berbeda tidak nyata dengan perlakuan $\mathrm{C}$ sedangkan perlakuan $\mathrm{A}$ dan $\mathrm{B}$ tidak berbeda nyata $(\mathrm{P}<0,05)$. Hal ini menunjukkan bahwa pemberian pakan suplemen daun singkong nyata meningkatkan kadar lemak dadih.

Meningkatnya kadar lemak dadih seiring dengan meningkatnya pemberian pakan suplemen daun singkong disebabkan pakan suplemen berfungsi sebagai sumber karbohidrat mudah terlarut dan protein lolos degradasi. Adapun karbohidrat merupakan prekursor glukosa yang dalam proses fermentasi oleh mikroorganisme rumen akan menghasilkan VFA diantaranya asam asetat sebagai bakal pembentukan lemak susu.

Keasaman. Hasil uji DMRT menunjukkan bahwa kadar asam laktat dadih pada perlakuan D (1,22\% TTA) paling tinggi diikuti secara berturut turut oleh perlakuan $\mathrm{C}$, B dan $\mathrm{A}$, namun berbeda tidak nyata dengan perlakuan $\mathrm{C}$. Meningkatnya keasaman dadih seiring dengan meningkatnya penambahan daun singkong ke pakan ternak kerbau. Nilai total asam diduga dipengaruhi oleh aktivitas bakteri asam laktat pada dadih selama proses perubahan laktosa susu menjadi asam laktat.

Rendahnya kandungan asam laktat yang dihasilkan pada perlakuan A (1,07\% TTA) disebabkan pada perlakuan A tidak ditambahkan daun singkong sebagai pakan ternak, sehingga nutrisi yang dihasilkan tidak sebanyak yang ditambahkan perlakuan. Akibatnya tidak dapat memacu aktivitas bakteri dadih dalam merombak laktosa menjadi asam laktat, sehingga asam laktat yang dihasilkan tidak banyak, yang artinya keasaman dadih yang dihasilkan pada perlakuan A rendah.

Viskositas Dadih. Hasil uji DMRT menunjukkan viskositas dadih pada perlakuan D nyata paling tinggi diikuti oleh viskositas dadih perlakuan B dan 
perlakuan A, namun berbeda tidka nyata dengan perlakuan $\mathrm{C}$. Ini berarti penambahan pakan suplemen daun singkong meningkatkan viskositas dadih.

Paling rendahnya viskositas dadih pada perlakuan A yaitu 1,85 Cpa disebabkan karena pada perlakuan A hanya menggunakan hijauan saja sebagai pakan, sehingga tambahan nutrien diharapkan yang akan menyebabkan kualitas susu meningkat tidak ada, sehingga tidak dapat memperbanyak aktifvtas bakteri dadih, dalam merombak laktosa menjadi asam laktat. Akibatnya asam laktat yang dihasilkan sedikit $\left(1,41 \times 10^{5} \mathrm{CFU} / \mathrm{ml}\right)$ sehingga koagulasi protein rendah dan kadar air tetap tinggi yang menyebabkan tekstur dadih menjadi kurang kental. Semakin menurun kadar air maka kadar protein dan viskositas akan mengalami peningkatan begitu juga sebaliknya.

\section{Pengaruh Pemberian Pakan Suplemen Terhadap Jumlah Telur Cacing Dalam Feses (EGP)}

Hasil perhitungan terhadap jumlah telur cacing per gram (EPG) pada feses kerbau yang diberi pakan suplemen TDS dapat dilihat pada Tabel 7.

Tabel 7. Rataan Jumlah Telur Cacing (Egg Per Gram/ EGP)Ternak Kerbau Hasil Penelitian

\begin{tabular}{cc}
\hline Perlakuan & Telur Cacing \\
\hline A & $5.600 \pm 1073.32^{\mathrm{a}}$ \\
B & $4.000 \pm 914.21^{\mathrm{b}}$ \\
C & $2.400 \pm 694.43^{\mathrm{c}}$ \\
D & $1.600 \pm 494.43^{\mathrm{c}}$ \\
\hline
\end{tabular}

Keterangan : Superskrip yang diikuti huruf kecil yang berbeda pada baris yang sama berbeda nyata $(\mathrm{P}<0,05)$ dan dengan huruf besar berbeda sangat nyata $(\mathrm{P}<0,01)$.

Hasil uji lanjut DMRTmenunjukkan bahwa perlakuan D sangat nyata paling rendah dibanding perlakuan B dan A namun berbeda tidak nyata dengan perlakuan C. Ini berarti bahwa pemberian pakan suplemen nyata menurunkan telur cacing per gram feses. Terjadinya penurunan telur cacing per gram feses pada perlakuan B, C dan D dibandingkan dengan perlakuan A tanpa perlakuan pakan suplemen daun singkong karena pakan suplemen daun singkong mengandung protein yang memiliki efek pada telur cacing (Netpana et al., 2001). Hal ini disebabkan pengaruh langsung dari adanya tanin terkondensasi 
(Anthanasiadou et al., 2000; Molan et al., 2000) atau pengaruh tidak langsung seperti peningkatan suplai protein ke saluran pencernaan (Bown et al., 1991; Wanapat, 2000). Seng Sokerya dan Preston (2003) menunjukkan bahwa telur cacing per gram feses (EPG) pada kambing diberi pakan daun singkong terus menurun selama penelitian dari sekitar 4,000-5,000 telur / g kotoran segar di 30 hari pertama dan menurun sekitar 1.500 telur / g setelah 70 hari.

\section{Pengaruh Pakan Suplemen terhadap Gejala Reproduksi Ternak Kerbau}

Penelitian gejala reproduksi dilakukan untuk mengetahui pengaruh pakan suplemen daun singkong terhadap gejala reproduksi terutama estrus pertama postpartum, kadar hormon prolaktin dan progesteron.

\section{Pengaruh Pakan Suplemen Terhadap Estrus Pertama Postpartum}

Proses terjadinya estrus sangat erat kaitannya dengan mekanisme sistim hormonal. Pada saat estrus konsentrasi estrogen meningkat sesuai dengan pertumbuhan folikel de graaf karena folikel tersebut memproduksi hormon estrogen. Selanjutnya di bawah pengaruh LH yang disekresikan oleh hypopisa anterior terjadi ovulasi yang akan melepaskan sel telur dan terjadi pembentukan corpus luteum, sehingga terjadi peningkatan hormon progesteron yang disekresikan oleh corpus luteum dan konsentrasi estrogen menurun (Azis et al., 1993). Konsentrasi progesteron secara cepat akan meningkat pada tiga siklus ovari pertama di awal laktasi dan laju peningkatannya menurun akibat dari keseimbangan energi negatif.

Dengan demikian suplementasi secara keseluruhan diharapkan dapat memberikan pengaruh yang baik terhadap peningkatamn protein mikroba, daya cerna dan konsumsi pakan sehingga diperoleh keseimbang yang baik antara asam amino dan energi di dalam zat-zat makanan yang terserap sehingga dapat meningkatkan reproduksi. Lamanya periode tidak berahi setelah melahirkan bervariasi menurut bangsa dan tampaknya menjadi konstan pada betina yang sama pada kebuntingan yang berturut-turut (Suardi, 2008).

\section{Pengaruh Pemberian Tepung Daun Singkong Terhadap Hormon Prolaktin dan Progesteron}


Rataan kadar hormon prolaktin dan progesteron darah kerbau laktasi dengan pemberian pakan suplemen Daun Singkong dapat dilihat pada Tabel 8.

Tabel 8. Rataan Kadar Hormon Prolaktin dan Progesteron Darah Kerbau Setelah diberi Pakan Suplemen Selama 90 hari Pasca Melahirkan

\begin{tabular}{ccccc}
\hline \multirow{2}{*}{ Peubah } & \multicolumn{4}{c}{ Perlakuan } \\
\cline { 2 - 5 } & A & B & C & D \\
\hline Prolaktin $(\mathrm{ng} / \mathrm{ml})$ & $1,29 \pm 0,12$ & $1,46 \pm 0,26$ & $1,48 \pm 018$ & $1,46 \pm 0,20$ \\
Progesteron $(\mathrm{ng} / \mathrm{ml})$ & $2,68 \pm 0,11^{\mathrm{b}}$ & $2,69 \pm 0,29^{\mathrm{b}}$ & $4,63 \pm 0,95^{\mathrm{a}}$ & $4,42 \pm 1,21^{\mathrm{a}}$ \\
\hline
\end{tabular}

Keterangan : Superskrip yang diikuti huruf kecil yang berbeda pada baris yang sama berbeda nyata $(\mathrm{P}<0,05)$ dan dengan huruf besar berbeda sangat nyata $(\mathrm{P}<0,01)$.

Prolaktin. Hasil analisis keragaman terlihat bahwa pemberian pakan suplemen daun singkong tidak memberikan pengaruh yang nyata $(\mathrm{P}>0,05)$ terhadap kadar hormon prolaktin. Ini berarti tidak terdapat hubungan yang nyata $(\mathrm{P}>0,05)$ antara kadar hormon prolaktin dengan pemberian pakan suplemen. Ratarata kadar hormon prolaktin adalah $1,36 \mathrm{ng} / \mathrm{ml} \pm 0,19 \mathrm{ng} / \mathrm{ml}$. Rata-rata kadar hormon prolaktin pada penelitian ini hampir sama dengan yang didapat oleh Bell dan Holtz (2005) bahwa setelah melahirkan kadar hormon prolaktin 1,9 $\pm 0,2$ $\mathrm{ng} / \mathrm{ml}$ dan induk yang diberi suplementasi multinutrien blok $2,3 \pm 0,3 \mathrm{ng} / \mathrm{ml}$, kemudian menurun pada level 1,7 $\pm 0,1 \mathrm{ng} / \mathrm{ml}$ dan $1,9 \pm 0,2 \mathrm{ng} / \mathrm{ml}$, dan bertahan pada level ini sampai minggu ke 16 laktasi. Hal ini mungkin disebabkan bangsa atau jenis kerbau, spesies, dan sistem pemeliharaan. Bell dan Holtz (2005) berpendapat bahwa ternak yang digembalakan di padang penggembalaan alam sebelum dan sesudah melahirkan tidak mempengaruhi kadar hormon prolaktin.

Progesteron. Hasil uji DMRT menunjukkan bahwa kadar hormon progesteron pada perlakuan $\mathrm{C}$ sangat nyata paling tinggi dibandingkan perlakuan lainnya, tetapi berbeda tidak nyata dengan perlakuan D.Kadar hormon progesteron pada perlakuan B berbeda tidak nyata dengan perlakuan A. Ini berarti bahwa pemberian pakan suplemen daun singkong nyata meningkatkan kadar progesteron.

Peningkatan kadar hormon progesteron dalam darah diasumsikan erat kaitannya dengan tambahan asupan pakan suplemen yang diberikan mengandung protein dan energi, sesuai dengan pernyataan (Mc.Donald et al., 1995), pemberian pakan suplemen daun singkong yang mengandung sumber energi, protein, 
mineral dan vitamin pada kerbau pasca melahirkan dapat memicu perkembangan folikel. Schillo (1992) menyatakan energi tubuh yang cukup dapat digunakan untuk meransang pertumbuhan folikel atau untuk mengaktifkan fungsi ovarium sehingga terjadi berahi kembali setelah melahirkan. Wiltbank et al. (1964) menyatakan perbaikan nutrisi mampu menunjukkan perbaikan fungsi ovarium.

\section{KESIMPULAN DAN SARAN}

\section{Kesimpulan}

Berdasarkan hasil penelitian dan pembahasan yang telah dilakukan dapat disimpulkan sebagai berikut:

1. Pemberian daun singkong sebagai pakan suplemen sebanyak 10\% (Perlakuan B) dapat meningkatkan karakteristik cairan rumen secara in-vitro yaitu VFA, total bakteri rumen, $\mathrm{KCBK}, \mathrm{KCBO}$ dan menurunkan konsentrasi $\mathrm{NH}_{3}$ serta $\mathrm{pH}$ cairan rumen yang normal.

2. Pemberian daun singkong sebagai pakan suplemen sebanyak $1,5 \mathrm{~kg} / \mathrm{hr}$ memberikan performans produksi terbaik dengan meningkatnya kadar, glukosa dan protein darah kerbau. Pemberian pakan suplemen sebanyak 1,5 $\mathrm{kg} / \mathrm{hari}$ mampu meningkatkan persentase produksi susu sebesar 40,62\% dengan rata-rata produksi susu (7\% FCM) 1,35 kg/ekor/hr atau 1,67 1/ekor/hr dan peningkatan komposisi susu yaitu protein, lemak dan laktosa serta menurunkan kadar air susu. Pemberian pakan suplemen daun singkong dapat meningkatkan kualitas dadih dan nilai organoleptik (rasa dan tekstur) dadih yaitu protein, lemak, BAL, keasaman, viskositas, menurunkan kadar air dan meningkatkan organoleptik rasa serta tekstur. Pemberian pakan suplemen efektif sebagai kontrol helminthiasis.

3. Pemberian daun singkong sebagai pakan suplemen tidak berpengaruh pada hormon prolaktin tetapi dapat meningkatkan hormon progesteron.

\section{Saran}

1. Ternak kerbau yang diperah yang dipelihara di padang penggembalaan perlu diberikan pakan suplemen untuk meningkatkan protein hijauan yang berkualitas rendah, dapat diintegrasikan dalam pakan konsentrat. 
2. Pemberian daun singkong sebagai pakan suplemen dengan dosis sebanyak 1,5 $\mathrm{kg} / \mathrm{ekor} / \mathrm{hr}$ merupakan pemberian yang optimal dan perlu dilakukan penelitian lanjutan dengan peningkatan pemberian pakan suplemen sebanyak 2,0 $\mathrm{kg} / \mathrm{ekor} / \mathrm{hr}$.

\section{DAFTAR PUSTAKA}

Akter, Y., M.A. Akbar, M. Shahjalal and T.U. Ahmed. 2004. Effect of urea multinutrient block supplementation of dairy cow fed rice straw and green grasses on milk yield, composition, live weight gain of cows and calves and feed intake. Pakistan J. Biol. Sci. 9: 1523-1525.

Athanasiadou, S., I. Kyriazakis, F. Jackson and R. L. Coop. 2000. Effects of short-term exposure to condensed tannins on adult Trichostrongylus colubriformis. Vet. Rec. 146:728-732.

Azis, A. A., dan Partodiharjo, S., R. Widjajakusuma., dan C. Hendratna., 1993. Hubungan Antar Marfologi Ovarium dan Tingkatan Progesteron Dalam Darah dan Extrak Ovarium pada Fase Folikel, Luteal dan Bunting pada Kambing Peranakan Etawah (Capra hircus). Pertemuan Ilmiah Aplikasi Isotop dan Radiasi. PAIR BATAN. Jakarta State University Press. Ames. Pp 1 3-38.

Banerjee B.C. 1980. Animal Nutrition. Oxford and IBH Publishing Co., Bombay,Calcuta, NewDelhi. Pp 586-599.

Bell dan Holtz. 2005. Pola Hormonal Induk Sapi Bali yang diberi Suplementasi Multinutrien Blok Sebelum dan Sesudah Melahirkan. Seminar Nasional Teknologi Peternakan dan Veteriner. Fakultas Peternakan Universitas Nusa Cendana Kupang, Nusa Tenggara Timur

Bergman E.N., W.E. Roe, and K. Kohn. 1966. Quantitative Aspects of PropionateMetabolism and Glukoneogenesis in Sheep. L Physiol. 211:793799.

Czerkawski, J.W. 1986. An Introduction to Rumen Studies. Pergamon Press. Oxford, Toronto, Sidney, Frunkfurt. 3-10; 19-27.

Foiklang, S., M. Wanapat and W. Toburan. 2011. Effect of Various Plant Protein Sources in High-qualiti Feed Block on Feed Intake, Rumen Fermentation and Mikrobial Population in Swamp Buffalo. Trop Anim Health Prod 43.2.1517-1524.

Fuller, R. 1992. Probiotic 1. The scientific Basic. $1^{\text {st }}$ Ed Chapman \& Hall, London.

Granum, G., M. Wanapat, P. Pakdee, C. Wachirapakorn and W. Toburan. 2007. A comparative study on the effect of cassava hay supplementation in swamp 
buffaloes (Bubalus bubalis) and cattle (Bos indicus). Asian-Aust. J. Anim. Sci. 20(9): 1389-1396.

Hong, N. T. T., M. Wanapat, C. Wachirapakorn, P. Pakdee and P. Rowlinson. 2003. Effects of timing of initial cutting and subsequent cutting on yields and chemical compositions of cassava hay and its supplementation on lactating dairy cows. Asian-Aust. J. Anim. Sci. 16:1763-1769.

Ibrahim, L. 2008. Produksi susu, reproduksi dan manajemen kerbau perah di Sumatera Barat. Jurnal Peternakan, 5 (1): 1- 9.

Jalaludin. 1994. Uji banding gamal dan angsana sebagai sumber protein, daun kembang sepatu dan minyak kelapa sebagai agen defaunasi dan suplementasi analog hidroksi metionin dan amonium sulfat dalam ransum pertumbuhan sapi perah jantan. Tesis. Fakultas Pascasarjana. Institut Pertanian Bogor, Bogor.

Khang, D. N., H. Wiktorsson and T. R. Preston. 2005. Yield and chemical composition of cassava foliage and tuber yield as influenced by harvesting height and cutting interval. Asian-Aust. J. Anim. Sci. 18:1029-1035.

Leng R.A, J.W. Steel and J.R. Luick, 1967. Contribution of propionate to glucose synthesis in sheep. Biochem. J. 103-785.

Mc. Donald, P., R. A. Edwards, J. F. D. Greenhalgh, C. A. Morgan. 1995. Animal Nutrition. Fifth Edition. Longman Scientific \& Technical, New York

Netpana, N., M. Wanapat, O. Poungchompu and W. Toburan. 2001. Effect of condensed tannins in cassava hay on fecal parasitic egg counts in swamp buffaloes and cattle. In: Proc. Interntional Workshop on Current Research and Development in Use of Cassava as Animal Feed, July 23-24, 2001, Khon Kaen University, Thailand. pp. 41-43.

Nurhaita, N. Jamarun, L Warly, \& Mardiati Z. 2010. Sintesis protein mikroba pada domba yang mendapat ransum daun sawit amoniasi yang disuplementasi mineral S,P dan daun ubi kayu. Jurnal Penelitian Universitas Jambi Seri Sains. 12: 107-114

Orskov, E. R. 1982. Protein Nutrition in Ruminants. Academic Press, New York

Phuc, B.H.N., B. Ogle and JE Linberg . 2008. Nutritive value of cassava leaves for monogastric animals. http//WW $\backslash$ N.mekarn .org/procKKJphuc.htm Diakses tanggal 17/12/2008

Preston, T. R. dan R. A. Leng. 1987. Matching Ruminant Production and Systems with Available Resources in the Tropics and SubTropics. Penambul Books, Armidale. 
Reksohadiprodjo, S. 1985. Produksi Tanaman Hijauan Makanan Ternak Tropika. Bagian Penerbitan Fakultas Ekonomi (BPFE), Universitas Gadjah Mada. Yogyakarta.

Riis PM. 1983. Adaptation of metabolism to various condition. Di dalam Riis PM Editor. Dynamic Biochemistry of Animal Production. Tokyo: PM. Elsevier. Hlm. 319 - 353.

Roza, E. 2009. Penerapan Aspek Teknis Pemeliharaan Ternak kerbau Di Kecamatan Lembah Gumanti Kab. Solok. Laporan Penelitian Dipa Kompetitif, Unand Padang.

Schillo, K. K. 1992. Effect of dietary energy on control of luteinizing hormone secretion in cattle and sheep. J. Anim. Sei. 70:1.271-1.282.

Shamilima, G.Y.C., N.J. Siulapwa, H.W. Witola, K. Muzandu and G. Sikazwe. 2000. Field evaluation of feed supplementation package for improving milk production using locally available feed resource in Zambia. Indian J. Vet. Res. 9: 55-58

Siregar, S. 1999. Ransum Ternak Ruminansia. Penerbit PT. Swadaya, Jakarta.

Steel, R.G.D., and J.H. Torrie. 1991. Prinsip dan Prosedur Statistik. Suatu Pendekatan Biometrik. Alih bahasa. B. Sumantri. Gramedia. Jakarta.

Suardi, M. S. 2008. Memperpendek Jarak Beranak Untuk Meningkatkan Populasi Pada Sapi Potong. Fakultas Peternakan Universitas Andalas, Padang.

Suryahadi, K.G. Wiryawan, I.G. Permana, H. Yano and R. Kawashima. 1996. The use of local yeast culture Saccharomyces cerevisiae to improve fermentation and nutrient utilization of buffaloes. Proc. 8. AAAP Anim. Sci Congress. 2: $168-169$.

Susetyo. 1980. Padang Pengembalaan. Departemen Ilmu Makanan Ternak. Fakultas Peternakan Institut Pertanian Bogor. Bogor.

Sutardi, 1977. Metabolism of some essential amino acids by rumen microbes with special reference to alpha-keto acids. Ph-D- Thesis, University of Wisconsin Medison.

Sutardi ,T. 1980. Ilmu Gizi dan Makanan Ternak. Fakultas Peternakan IPB, Bogor.

Wanapat, M. 2000. Rumen manipulation to increase the efficient use of local feed resources and productivity of ruminants in the tropics. Asian-Aust. J. Anim. Sci. 13(Suppl.):59-67. 
Wanapat, M. 2000. Role of cassava hay as animal feed in the tropics. In: Proc. Interntional Workshop on Current Research and Development in Use of Cassava as Animal Feed. July 23-24, 2001, Khon Kaen University, Thailand. pp. 13-19.

Wanapat, M. 2009. Potential uses of local feed resources for ruminants. Trop. Anim. Health and Production, 41(7): 1035-1049.

Wanapat, M. and S. Khampa. 2006. Effect of cassava hay in high-quality feed block as anthelmintics in steers grazing on ruzi grass. Asian-Aust. J. Anim. Sci. 19:695-698.

Wanapat, M., A. Petlum and O. Pimpa. 1999. Strategic supplementation with a high quality feed block on roughage intake, milk yield and composition and economic return in lactating dairy cows. Asian-Aust. J. Anim. Sci. 12: 901903

Whitbank, W.H. 1964. Some modification of the McMaster helminth eggcounting technique and apparatus. J. Council Sci. Industrial Rese.21: 117118.

Wikantadi, B. 1978. Biologi Laktasi. Bagian Ternak Perah, Fakultas Peternakan Universitas Gadjah Mada. Yogyakarta.

Wirdahayati R B dan Bamualim Abdullah M. 2007. Pemanfatan Daun Gamal (Gliricida-Sepium) Sebagai Pakan Suplemen Ternak Kerbau Penghasil Dadih di Sumatera Barat. Seminar Lokakarya Nasional Usaha Ternak Kerbau 2007. Balai Besar Pengkajian dan Pengembangan Teknologi Pertanian Bogor. Pusat Penelitian dan Pengembangan Peternakan Bogor. 